Copyright (C) 2014 by Academic Publishing House Researcher

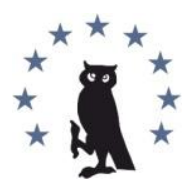

Published in the Russian Federation

European Researcher

Has been issued since 2010.

ISSN 2219-8229

E-ISSN 2224-0136

Vol. 83, No. 9-2, pp. 1682-1693, 2014

DOI: 10.13187/er.2014.83.1682

www.erjournal.ru

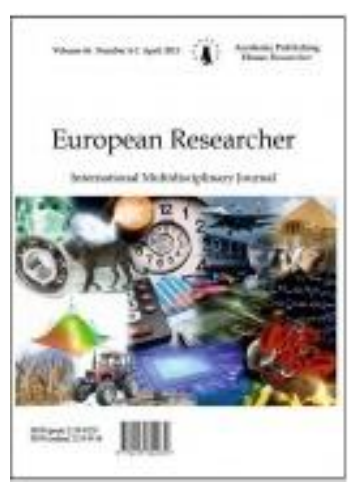

Pedagogical sciences

Педагогические науки

\title{
The Learning of Mind Mapping in Higher Education: A Comparative Study Between Universidad de Córdoba and Università di Roma-La Sapienza
}

\author{
${ }^{1}$ Muñoz González \\ ${ }^{1}$ Juan Muñoz \\ ${ }^{1}$ Vega Gea \\ ${ }^{1}$ Esther María \\ 2 Figueroa Flores \\ ${ }^{2}$ Jorge Francisco
}

${ }^{1}$ Department of Education, University of Córdoba, Córdoba, 14071, Córdoba, Spain

${ }^{2}$ Department of Social \& Human Sciences, Eastern University, Puerto Rico

\begin{abstract}
In this paper we propose Mind Mapping as a technique which enhances holistic learning or whole brain learning in higher education. The dynamics performed in the learning and application of Mind Mapping is part of a participatory approach in the classroom as an element of the learning process. The research approach follows a quantitative methodology. The results reflect the views of students about the learning of Mind Mapping and its effectiveness in the study. The findings indicate that mental maps can be used with any type of material, making it a tool applicable to any university degree course.

Keywords: Mind Maps; holistic learning; brain hemispheres; creative thinking; thinking and learning; self-learning; participatory methodology.

\section{Introduction}

Current education and training of teachers in all educational stages need new strategies and techniques to respond to the society of information and communication. At the same time, advances in the research of the brain and it function have opened new perspectives on learning. This includes an educational approach that aims and fosters the holistic learning of a person. This strategy permits to learn using the whole brain.

In this sense the goal is to convert the amount of information available today through personal knowledge processing. According to McCarthy (1991) "knowledge is the result of personalized information, it convert the mass of incoming data significant concepts and images. This process is developed reflecting on the information that comes with understanding, evaluating it and translating it into the language that we use" (p.142). An enabling strategy of such conversion is Mind Mapping. According to Buzan (1996), "can be defined as a graphical technique that takes advantage of all cortical capabilities and implement the potential of the brain" (p. 175) and can be
\end{abstract}


applied in all ages and professions to encourage creative thinking in line with the knowledge society of the twenty-first century.

\section{Mind Mapping and the Impact on Learning}

This section will briefly reflect on Mind Mapping as a learning technique. It will include it's origin, conceptualization, and it's relevance with current theoretical approaches.

\section{Origin of Mind Mapping}

The origin and development of Mind Mapping is connected with the movement of cognitivism or the "cognitive revolution", consolidated during the decade 70-80 of the twentieth century. The cognitive thinking evolved focusing in the mechanisms of acquisition of information and skills to understand the meaning and the creation of new cognitive structures.

Tony Buzan, is considered the creator of Mind Mapping through his book "The Mind Map Book (1996) along with the Spanish edition of "Tu mente en forma" (2004). In addition Antonio Ontoria, has led to the spread of this technique in Spain with his books books "Potenciar la capacidad de aprender y pensar" (2007, 4th edition) and "Aprender con Mapas Mentales " (2006, 4th Ed.)

\section{Existing theoretical approaches and the relationship with Mind Mapping}

For the theoretical foundation of Mind Mapping as a learning technique strategy, there are three relevant scientific approaches:

1) The Development of Neuroscience: In order to explain the brain function three major theorists, Sperry (1973), MacLean (1978, 1990), and Herrmann (1989), are cited. In regards to field of learning and integrating it to brain research the work of Carter (2002) and Jensen (2003) is exposed.

2) The "Visualization of Information" and the Expansion of TIC's in Society: The use of the Mind Mapping technique is associated with the construction of knowledge through graphic organizers for visual learning (Tufte, 1994; Wurman, 1997, Dürsteler, 2000; Engelhart, 2002. Ware, 2004). The mind map is by definition a graphic expression of thought, and using the "neuron" as an analogy it applies the idea of irradiating, simultaneously imaginative and structured thinking (Buzan, 1996, 2004; Ontoria, 2004, 2006). The connection between information technology and audiovisuals fully respond to the teacher training need for this century.

3) Multiple Intelligences and Emotional Intelligence: Finally, the concept of "multiple intelligences" by Gardner (1994) and the movement of emotional intelligence through the work of Goleman $(1998,2006)$ are mentioned based on their support for a holistic approach toward learning.

\section{Conceptual perspective of Mind Mapping}

In this subsection, three definitions of Mind Mapping are collected:

"It's an expression of radiant thinking and therefore a natural function of the human mind. It is a powerful graphic technique, which offers a master key to access the potential of the brain." (Buzan, 1996, p. 69)

"Mind Mapping is a powerful graphic technique that leverages the full range of cortical skills and starts the real potential of the brain" (Buzan, 1996, p. 175).

"A method that distills the essence of what we know and organize it visually". (McCarthy, 1991, p. 142)

Also three aspects to facilitate a better understanding of Mind Mapping as a learning technique are developed, including:

1. Main characteristics: Buzan (1996), mentions that mind maps are "powerful graphic techniques that triggers the true potential of the brain" (p.69). The Mind Map is a multidimensional reality that includes space, time and color (p. 175). They are characterized for thinking and combining words and images, classifying and categorizing (Ontoria et al., 2006). The word is considered, in Western thought, a sign of mental maturity, while the use of images is labeled as a sign of immaturity. This view reflects a cultural mindset in which the word is the main instrument of communication and information. However, the image connects with diverse skills in the brain related to shapes, colors, lines, dimensions, etc. Those skills stimulate the imagination and encourage creative thinking and memory. Currently, the integration between both areas and the integration to the brain is enhanced. McCarthy (1994) specifies more elements in Mind Mapping including: personal commitment, multichannel learning, organization, association, and 
visual images. These basic components are the "laws of Mind Mapping" (Buzan, 1996, p.113), which are the terms of reference for the construction of mental maps that are synthesized in the search for emphasis, association, clarity and personal style. Finally, classification and categorization is highlighted, which facilitate the management and structuring of thought. An expression used to achieve this is to identify the basic orders of ideas. These are the key concepts from which a frame of new concepts in terms of their importance is organized.

2. Radiant thinking and expression of Mind Mapping: The thought of radiant expression is referred to the mental structure of Mind Mapping. In order to explain this idea an analogy is presented in the concept of the neuron and the tree. The neural functioning with multiple branches, and the tree as an image of the graph structure intended to reflect graphically the radial structure of Mind Mapping. The thematic core or motivating issue is the central image (trunk), from where the main ideas of the subject are presented in a branched form and departing from a center it branches in different directions. The branches include a picture or a printed word with a line associated. The minor points are also represented as branches attached to higher level branches. The mind map, therefore, tries to reflect graphically the radial structure, establishing relationships that are the basis for building the mind maps. Buzan (1996) uses the expression radiant thinking to mean "associative thought processes that come from a central point or connect with it" (p. 67).

3. Metacognitive function of Mind Mapping: The movement of metacognition considers that people, tasks and strategies form the basis of metacognitive activity. This is understood as the ability to combine and balance information from the three interactively considered aspects. From his choice of an interpretive - phenomenological model McCombs (1993) argues that self-awareness of the processes experienced in metacognitive activity reflects the involvement of the oneself as agent of learning. On the other hand the optimization of learning is related to an awareness of responsibility to the expectations and confidence in the possibilities for the effort involving the tasks. With Mind Mapping cognitive and social skills along with personal capabilities are enhanced. Definitely the concept of Mind Mapping is tuned with a holistic approach toward education and learning.

\section{Research design}

1. Research objectives

The main purpose of this study is to know the perceptions of the students regarding the learning process of mental mapping through an active and participative methodology in the classroom, in order to acquire specific content of a transversal theme in the undergraduate program of elementary education at Universidad de Córdoba and Communication Sciences at Università di Roma-La Sapienza, as is that of Social Media. This purpose is based following these specific objectives:

- To analyze the perception of university students about the learning process of mental mapping as learning technique based on gender, age and nationality of the participants in the study.

- To analyze the relationship between the different scale and dimensions of learning perception of mental mapping.

2. Dynamics of learning

The learning dynamics followed for the design and implementation of this study was similar to that developed by Muñoz and Marín Serrano (2014), which is divided into:

1. An introductory phase in the process of developing the mind maps, determined by an explanation of the technical characteristics and the development process.

2. First phase contact where the students were invited to make a first exploratory reading, followed by a second reading comprehension which facilitated the selection of the main and secondary ideas for the document along with synthesis on keywords.

3. A Mind Mapping manual assembly phase where finally, key words obtained in the previous phase, are used to form the mental map, using, in turn, drawings or pictures related to them, and the use of colors and shapes that facilitate understanding and memorizing the same subsequent recall of knowledge. 
3. Participants The students who participated in this research has been surveyed at the end of the learning process. We collected data from college students enrolled in the undergraduate degree of elementary education from Universidad de Córdoba, and college students enrolled in the degree of Communication Sciences at the Università di Roma-La Sapienza during the 2011-2012 academic year. This exploratory study, had a sample of 130 participants, 65 Italian students (Università di Roma-La Sapienza) and 65 Spanish students (Universidad de Córdoba). A total $69.2 \%$ of students were female and $38.2 \%$ male, with a mean age of 23 years.

4. Data collection instruments

In order to determine the degree of achievement of the objectives, we proceeded to apply at the end of the experience, a questionnaire that measured the application of Mind Mapping as a learning strategy for skills development within the convergence model (EHEA) of student centered learning. The original questionnaire consisted of a total of 25 items measured on four Likert scale items ( 1 = never, 2 = little, $3=$ somewhat, 4 = very much). However, this work only used 16 items responding to the sentiment analysis arising during the learning technique $(\alpha=.671)$, the analysis of emerging learning difficulties $(\alpha=.716)$ and analysis the positive aspects of the application of the technique $(\alpha=.893$.). The reliability of the overall scale was demonstrated as Cronbach coefficient obtained a value of .703, score enough, according to Matthew (2006) to consider that the instrument is reliable. The validation of the instrument was made by a group of experts in the field, from different Spanish and Italian universities whose process led to the reduction of the questionnaire from 25 to 16 items, as shown below in Table 1.

Also some demographic data of the students was taken into account in the study. To do this, students were asked to reply to questions about their gender, age, nationality and academic major.

\section{Table 1: Student perception questionnaire about the process of learning the technique of Mind Mapping}

Indicate the degree of agreement of the following statements under the rating scale:

Never (1), Little (2), Somewhat (3) and Very much (4).

\begin{tabular}{|c|c|c|c|c|}
\hline 1. I got doubts & 1 & 2 & 3 & 4 \\
\hline 2. Ifelt distressed & 1 & 2 & 3 & 4 \\
\hline 3. I was confused & 1 & 2 & 3 & 4 \\
\hline 4. Problems with space & 1 & 2 & 3 & 4 \\
\hline 5. Problems with amount of text & 1 & 2 & 3 & 4 \\
\hline 6. Problems with content structure & 1 & 2 & 3 & 4 \\
\hline 7. Problems with adaptation & 1 & 2 & 3 & 4 \\
\hline 8. Problems with the elaboration of the map using the computer & 1 & 2 & 3 & 4 \\
\hline 9. Problems to draw & 1 & 2 & 3 & 4 \\
\hline 10. Problems to synthesize ideas and concepts & 1 & 2 & 3 & 4 \\
\hline 11. Facilitated the understanding of issues worked & 1 & 2 & 3 & 4 \\
\hline 12. Facilitated the synthesis of information & 1 & 2 & 3 & 4 \\
\hline 13. Facilitated the organization of content & 1 & 2 & 3 & 4 \\
\hline 14. Provided comprehensive memorization of content & 1 & 2 & 3 & 4 \\
\hline 15. Facilitated remembering content & 1 & 2 & 3 & 4 \\
\hline 16. Facilitated the recall of subjects worked & 1 & 2 & 3 & 4 \\
\hline
\end{tabular}

\section{Data Analysis}

Data was analyzed using SPSS v.18.0 statistical package. Frequency analyses were used to describe the responses of students in the various items evaluated in the questionnaire. To compare the mean scores of the variables, when there were only two possible values in the grouping variables, Student T-test was used. An example included the Student T-test measure of the mean difference between the different scales of the instrument and the gender and nationality of the participants. In addition, the Pearson $r$ coefficient was used to estimate the effect size (Brysbaert, 2011; Field, 2009), with values between .10 and .30 which indicated little effect; values between .30 and .50 which indicated a medium effect; and finally, the values of 50 or higher the broad effect pointing. Moreover, to measure the mean difference between the different dimensions of the questionnaire and the age variable an Analysis of Variance (ANOVA) was performed. A Levene test was asked to check homogeneity of variances in both the Student T-test and the ANOVAs. In the 
case of the ANOVAs, post hoc multiple comparisons were performed to test mean differences between groups. These contrasts were on the Tukey tests when the variances were equal and Games-Howell when they were not (Pardo and Ruiz, 2002). At the same time, the Cohen's statistical d was used to measure the effect of size, being a value of 20 , indicating a small effect; a value from .50 moderate effects and a value of .80 or more indicated a large effect (Cohen, 1977). Finally, bivariate correlation analyzes were performed, and Pearson correlation coefficient was asked. Pearson values equal to \pm 1 indicate a large and perfect correlation values between \pm 9-99 would indicate a very high correlation, those who oscillate between \pm 0.7 and 0.89 would target a high correlation between .4 and $.69 \pm$ moderate correlation between .2 and $.39 \pm$ low correlation and a value of $\mathrm{o}$ would indicate no correlation between the measured variables.

\section{Results}

First, a descriptive analysis of frequencies and percentages was performed for the values of the items of the questionnaire on each of the 3 dimensions of the learning perception of Mind Mapping (see Table 2).

For dimension 1, which correspond to "feelings that arise during the learning of the technique" the results indicated that a high percentage of students (more than $50 \%$ of the sample) said they felt or feel little doubt, anguish or confusion during learning process. Specifically, 55.4\% did not emerge or show little doubt arose during the learning, 80.0\% did not feel or felt little worried, and $77.5 \%$ felt little or no confusion.

The data of dimension 2, which refer to the "emerging difficulties for learning the technique" indicated that students found greater difficulty in the process of developing the mind map related to the space, the amount of main and secondary ideas (text) and the synthesis of these concepts (47.6\% somewhat or very difficult space-related, $47.3 \%$ to the amount of text, and $49.3 \%$ with the synthesis of ideas into concepts). Aspects of learning that presented less difficulty for adapting included the development of mind maps using the computer and the making of drawings and pictures, as approximately $60 \%$ and $70 \%$ of students said they had no or have little trouble to adjust and develop mental maps and make drawings (67.9\%, 65.7\% and 60.5\% respectively). As for the problems related to the structure of the content, data suggested that approximately half of the sample experienced none or few problems, while the other half said enough or many problems to structure the contents of mental maps (see table 2).

Finally, the results of dimension 3, related to the "positive aspects of the application of the technique" indicated in all items evaluated that the use of the technique is fairly or very flattering. Data have shown that the aspects that facilitates the use of mind maps is the synthesis and organization of content studied, finding $86.8 \%$ of students said their application or provided them pretty much both the synthesis and the organization. It was also found that to a high percentage of students, the application of the technique of Mind Mapping provided enough or much understanding of content (72.9\%), comprehensive storage (69.9\%) and the memory (81.5\%) and the study (75.4\%) of the topics (see Table 2 ).

\section{Table 2: Descriptive of the items of the student perception questionnaire about the} process of learning the technique of Mind Mapping

\begin{tabular}{|c|c|c|c|c|}
\hline $\begin{array}{l}\text { ITEMS: Feelings that arise } \\
\text { during the learning of the } \\
\text { technique }\end{array}$ & (1)Never & (2)Little & $\begin{array}{l}\text { (3) } \\
\text { Somewhat }\end{array}$ & $\begin{array}{l}\text { (4) Very } \\
\text { much }\end{array}$ \\
\hline Igot doubts & $11(8.5 \%)$ & $61(46.9 \%)$ & $47(36.2 \%)$ & $11(8.5 \%)$ \\
\hline Ifelt distressed & $50(38.5 \%)$ & $54(41.5 \%)$ & $20(15.4 \%)$ & $6(4.6 \%)$ \\
\hline I was confused & $29(22.5 \%)$ & $71(55.0 \%)$ & $24(18.6 \%)$ & $5(3.9 \%)$ \\
\hline $\begin{array}{l}\text { ITEMS: Emerging difficulties of } \\
\text { learning the technique }\end{array}$ & (1)Never & (2)Little & $\begin{array}{l}\text { (3) } \\
\text { Somewhat }\end{array}$ & $\begin{array}{l}\text { (4) Very } \\
\text { much }\end{array}$ \\
\hline Problems with space & $23(17.7 \%)$ & $45(34.6 \%)$ & $44(33.8 \%)$ & $18(13.8 \%)$ \\
\hline Problems with amount of text & $17(13.2 \%)$ & $51(39.5 \%)$ & $39(30.2 \%)$ & $22(17.1 \%)$ \\
\hline Problems with content structure & $10(7.7 \%)$ & $64(49.2 \%)$ & $47(36.2 \%)$ & $9(6.9 \%)$ \\
\hline Problems with adaptation & $25(19.5 \%)$ & $62(48.4 \%)$ & $35(27.3 \%)$ & $6(4.7 \%)$ \\
\hline Problems with the elaboration of the & $33(30.6 \%)$ & $38(35.2 \%)$ & $23(21.3 \%)$ & $14(13.0 \%)$ \\
\hline
\end{tabular}




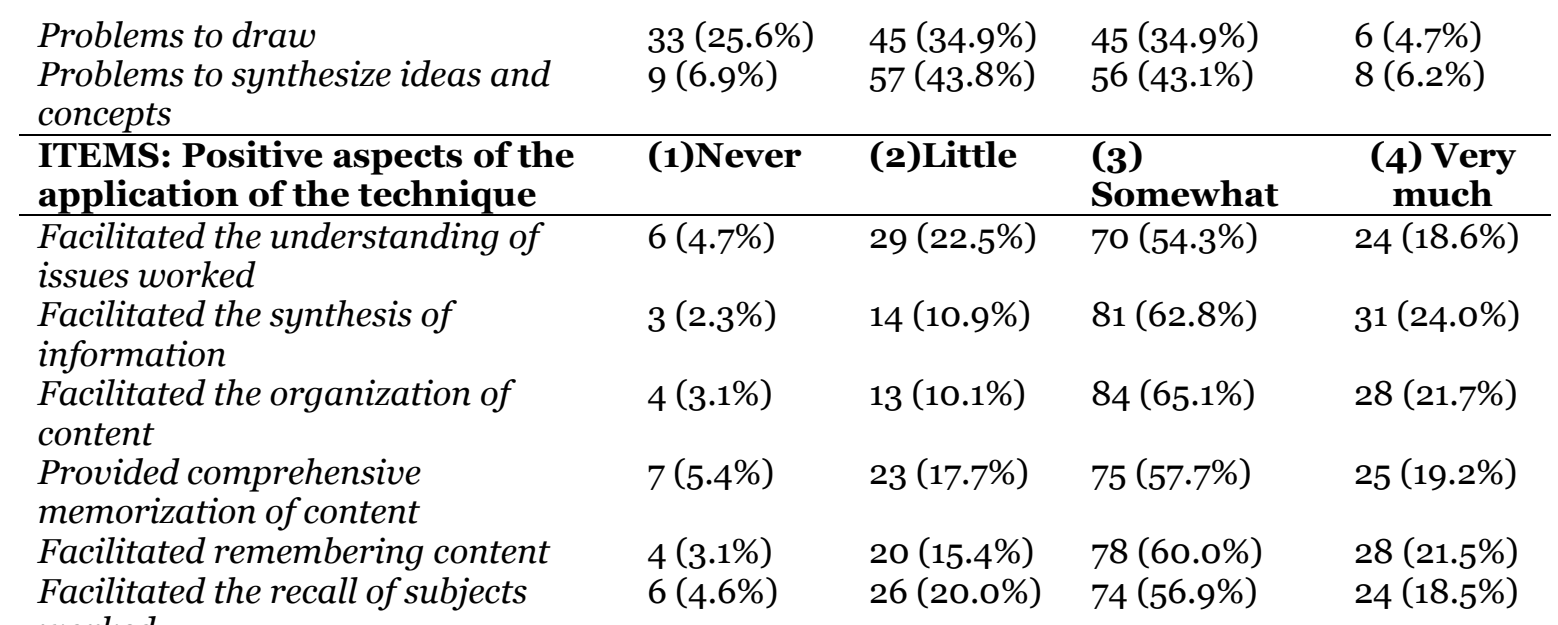
worked

$N=130$

A descriptive analysis of mean values was conducted, including the same, mean and standard deviation obtained on each of the items of the 3 dimensions of the questionnaire. In addition, the T-Student statistical test was applied to analyze comparatively the mean values of each variable, differentiating between males (Group 1, N = 40) and females (Group 2, $N=90$ ) who participated in the study. This analysis allows us to measure the relationship between different variables of the questionnaire and the gender of the students.

As it can be seen on Table 3, the results obtained show the relationship between the different variables of the questionnaire and the gender of the participants. In it, you can see the comparison of means for the two groups (males/ females). The 16 measured variables, belonging to the 3 dimensions of the questionnaire appear with abbreviated nomenclature on the subject to which it relates each item in the first column of the table (see Table 3).

The results of the Student T-test indicated no significant differences between the group of males and females in the studied variables. While descriptive noted that the means obtained in the items of the first dimension "Feelings that arise during the learning of the technique" were higher in the group of females, specifically in the variables doubt $(M=2.55$ vs. $M=2.40)$ and distress $(M=1.88$ vs. $M=1.86)$; and higher in the group of males in the confusion variable $(M=2.04$ vs. $M$ = 2.03). Descriptive variables for the second dimension "emerging difficulties of learning the technique" aimed a higher average for females in the space variables, making drawings and synthesis, while males had higher means in the variables related with the amount of text, content structure, adaptation and development of mind maps. In the descriptive of the third dimension "positive aspects of the application of the technique", the females showed higher average in comprehension, synthesis, storage and recall of information, while a higher mean in males, in organization and study (see table 3).

Since no statistically significant differences were found in any of the questionnaire items based on gender, the data suggest that learning the technique of Mind Mapping seems to imply no differences between boys and girls in any of its dimensions.

Table 3: Mean comparison between males and females

\begin{tabular}{llllll}
\hline $\begin{array}{l}\text { VARIABLE: FEELINGS THAT ARISE } \\
\text { DURING THE LEARNING OF THE } \\
\text { TECHNIQUE }\end{array}$ & Group & Mean & D.S. & Student-t & Sig. \\
\hline Doubts & & & & & \\
\hline \multirow{2}{*}{ Distress } & Male & 2.55 & .846 & 1.028 & .306 \\
\cline { 2 - 6 } & Female & 2.40 & .731 & & \\
\hline Confusion & Male & 1.88 & .791 & .121 & .904 \\
\cline { 2 - 6 } & Female & 1.86 & .868 & & \\
\hline VARIABLES: EMERGING & Male & 2.03 & .733 & -.138 & .890 \\
\cline { 2 - 6 } & Female & 2.04 & .767 & & \\
\hline
\end{tabular}




\begin{tabular}{|c|c|c|c|c|c|}
\hline \multicolumn{6}{|l|}{$\begin{array}{l}\text { DIFFICULTIES OF LEARNING THE } \\
\text { TECHNIQUE }\end{array}$} \\
\hline \multirow[t]{2}{*}{ Space } & Male & 2.33 & .797 & -.999 & .361 \\
\hline & Female & 2.49 & .997 & & \\
\hline \multirow[t]{2}{*}{ Text } & Male & 2.60 & .955 & .724 & .471 \\
\hline & Female & 2.47 & .918 & & \\
\hline \multirow[t]{2}{*}{ Content structure } & Male & 2.43 & .675 & .020 & .984 \\
\hline & Female & 2.42 & .764 & & \\
\hline \multirow[t]{2}{*}{ Adaptation } & Male & 2.33 & .772 & 1.529 & .129 \\
\hline & Female & 2.10 & .798 & & \\
\hline \multirow[t]{2}{*}{ Elaboration } & Male & 2.21 & .978 & .296 & .767 \\
\hline & Female & 2.14 & 1.033 & & \\
\hline \multirow[t]{2}{*}{ Drawings } & Male & 2.10 & 1.008 & -.689 & .493 \\
\hline & Female & 2.22 & .808 & & \\
\hline \multirow[t]{2}{*}{ Synthesis } & Male & 2.48 & .751 & -.101 & .919 \\
\hline & Female & 2.49 & .707 & & \\
\hline $\begin{array}{l}\text { VARIABLES: POSITIVE ASPECTS OF } \\
\text { THE APPLICATION OF THE } \\
\text { TECHNIQUE }\end{array}$ & Group & Mean & D.S. & Student-t & Sig. \\
\hline \multirow[t]{2}{*}{ Comprehension } & Male & 2.79 & .570 & -.716 & .475 \\
\hline & Female & 2.90 & .835 & & \\
\hline \multirow[t]{2}{*}{ Synthesis } & Male & 3.08 & .532 & -.094 & .925 \\
\hline & Female & 3.09 & .713 & & \\
\hline \multirow[t]{2}{*}{ Organization } & Male & 3.08 & .474 & .278 & .782 \\
\hline & Female & 3.04 & .737 & & \\
\hline \multirow[t]{2}{*}{ Memorization } & Male & 2.83 & .636 & -.904 & .368 \\
\hline & Female & 2.94 & .812 & & \\
\hline \multirow[t]{2}{*}{ Remembering } & Male & 2.98 & .577 & -.298 & .766 \\
\hline & Female & 3.01 & .757 & & \\
\hline \multirow[t]{2}{*}{ Study } & Male & 2.93 & .616 & .330 & .742 \\
\hline & Female & 2.88 & .805 & & \\
\hline
\end{tabular}

The possible relationship between the nationality of the students and the questionnaire variables were also analyzed. As was done with age, Student T-test were performed for analyzing possible differences of means between the group of Italian students and the group of Spanish students in the questionnaire variables used in the research.

In Table 4, the results of the descriptive analysis of mean values (mean and standard deviation of the mean), and the value obtained in the Student T-test performed to compare the mean values of each of the variables according to the nationality of the students can be seen (Spain, Group 1, N = 65 and Italy, Group 2, N =65). The names of each of the variables analyzed are shown in the first column of the table. In it, it has given a more abbreviated nomenclature for each of the items related to the topic to which it refers. Students T-tests showed significant differences in relation to the nationality of the participants in the study. Specifically, significant differences were found in the variables distress [ $\mathrm{t}(128)=5.836 ; \mathrm{p}=.000$ ] and confusion [ $\mathrm{t}(127)=3.264 ; \mathrm{p}=.001]$, both corresponding to the dimension "Feelings that arise during the learning of the technique", where Spanish students score higher than Italian students in the feelings related to distress and confusion that occur during the learning of mental mapping. The effect size was moderate $(\mathrm{r}=.46)$ for the item related to distress and small $(\mathrm{r}=.28)$ for the item on confusion, so the difference found between being Spanish or Italian and the confusion that arises during learning of mental mapping was largely influenced by the size of the sample, while the relationship between anxiety and nationality was little influenced by the sample size. In addition, statistically significant differences in relation to nationality were seen in the space variables $[\mathrm{t}(128)=2.177 ; \mathrm{p}=.031$ ] effect size $\mathrm{r}=$ .19 small-, amount of text $[\mathrm{t}(127)=4.414 ; \mathrm{p}=.000] \mathrm{r}=.36$ moderate-size effect, structuring content $[\mathrm{t}(128)=2.558 ; \mathrm{p}=.012] \mathrm{r}=.22$ small effect size, adaptation $[\mathrm{t}(125,190)=1.990 ; \mathrm{p}=$ 
$.049] \mathrm{r}=.18$ petty-size effect, and synthesis [t $(128)=3.434 ; \mathrm{p}=.001] \mathrm{r}=.29$ under- medium-size effect, all belonging to the dimension " emerging difficulties of learning the technique." For all variables, the group of Spanish students scored higher than the group of Italians. According to the data, the Spanish students said that arose further negative feelings during the learning technique, as well as greater difficulty learning emerging mental maps. However, no significant differences with regard to the nationality of the participants in any of the items in the third dimension "positive aspects of the application of the technique," so find that in our sample, the positive aspects the application of the technique are independent of the nationality of the participants in the study. However, although there are no statistically significant differences in all variables except for the memory variable, the Spanish students scored higher than the Italian students.

Table 4: Mean comparison between Italian and Spanish students

\begin{tabular}{|c|c|c|c|c|c|}
\hline $\begin{array}{l}\text { VARIABLE: FEELINGS THAT } \\
\text { ARISE DURING THE LEARNING OF } \\
\text { THE TECHNIQUE }\end{array}$ & Group & Mean & D.S. & Student-t & Sig. \\
\hline \multirow[t]{2}{*}{ Doubts } & Spain & 2.51 & .732 & .913 & .363 \\
\hline & Italy & 2.38 & .804 & & \\
\hline \multirow[t]{2}{*}{ Distress } & Spain & 2.25 & .867 & 5.836 & $.000^{* *}$ \\
\hline & Italy & 1.48 & .615 & & \\
\hline \multirow[t]{2}{*}{ Confusion } & Spain & 2.25 & .811 & 3.264 & $.001^{* *}$ \\
\hline & Italy & 1.83 & .631 & & \\
\hline $\begin{array}{l}\text { VARIABLES: EMERGING } \\
\text { DIFFICULTIES OF LEARNING THE } \\
\text { TECHNIQUE }\end{array}$ & Group & Mean & D.S. & Student-t & Sig. \\
\hline \multirow[t]{2}{*}{ Space } & Spain & 2.62 & .913 & 2.177 & $.031^{*}$ \\
\hline & Italy & 2.26 & .940 & & \\
\hline \multirow[t]{2}{*}{ Text } & Spain & 2.85 & .905 & 4.414 & $.000^{* *}$ \\
\hline & Italy & 2.17 & .827 & & \\
\hline \multirow[t]{2}{*}{ Content structure } & Spain & 2.58 & .768 & 2.558 & $.012^{*}$ \\
\hline & Italy & 2.26 & .668 & & \\
\hline \multirow[t]{2}{*}{ Adaptation } & Spain & 2.31 & .828 & 1.990 & $.049^{*}$ \\
\hline & Italy & 2.03 & .740 & & \\
\hline \multirow[t]{2}{*}{ Elaboration } & Spain & 2.25 & 1.09 & 1.053 & .295 \\
\hline & Italy & 2.05 & .872 & & \\
\hline \multirow[t]{2}{*}{ Drawings } & Spain & 2.20 & .922 & .182 & .856 \\
\hline & Italy & 2.17 & .827 & & \\
\hline \multirow[t]{2}{*}{ Synthesis } & Spain & 2.69 & .705 & 3.434 & $.001^{* *}$ \\
\hline & Italy & 2.28 & .673 & & \\
\hline $\begin{array}{l}\text { VARIABLES: POSITIVE ASPECTS } \\
\text { OF THE APPLICATION OF THE } \\
\text { TECHNIQUE }\end{array}$ & Group & Mean & D.S. & Student-t & Sig. \\
\hline \multirow[t]{2}{*}{ Comprehension } & Spain & 2.98 & .739 & 1.757 & .081 \\
\hline & Italy & 2.75 & .777 & & \\
\hline \multirow[t]{2}{*}{ Synthesis } & Spain & 3.15 & .537 & 1.188 & .237 \\
\hline & Italy & 3.02 & .766 & & \\
\hline \multirow[t]{2}{*}{ Organization } & Spain & 3.12 & .650 & 1.186 & .238 \\
\hline & Italy & 2.98 & .678 & & \\
\hline \multirow[t]{2}{*}{ Memorization } & Spain & 2.95 & .672 & .689 & .492 \\
\hline & Italy & 2.86 & .846 & & \\
\hline \multirow[t]{2}{*}{ Remembering } & Spain & 2.95 & .672 & -.746 & .457 \\
\hline & Italy & 3.05 & .738 & & \\
\hline \multirow[t]{2}{*}{ Study } & Spain & 2.98 & .673 & 1.409 & .161 \\
\hline & Italy & 2.80 & .814 & & \\
\hline $\mathbf{N}=130$ & & & & & \\
\hline
\end{tabular}

In order to statistically determine the effect of age on the perception of learning the technique of Mind Mapping, a comparison of means on each of the variables in the questionnaire 
was performed. Specifically, ANOVA were performed, as comparing the variable (age) had more than two response values.

In Table 5, the results obtained are shown, indicating significant differences by age in the following variables: distress $[\mathrm{W}(4,127)=8.077 ; \mathrm{p}=.00 ; \mathrm{d}=$.$] of dimension 1$ "feelings that arise during the learning of the technique", being the differences between the age group of 19-20 years with the group 23-24 and 25-26 years, with younger students presented higher mean anxiety than the other two older age groups (23-24 and 25-26 years); synthesis of ideas into concepts [W (4, $127)=6.889 ; \mathrm{p}=.00 ; \mathrm{d}=$.$] , the second dimension of the scale "emerging difficulties of learning the$ technique", pointed out the differences between the group of students between 25-26 years with the group of students of 19-20 years and with more than 26 years , being the 25-26 years group said lower half problems with the synthesis of ideas into concepts students 19-20 years group and that group over 26 years; variables regarding understanding $[\mathrm{W}(4,126)=3.315 ; \mathrm{p}=.022 ; \mathrm{d}=]$ and organization $[\mathrm{W}(4,127)=3.621 . ; \mathrm{p}=.014 ; \mathrm{d}=$.$] , while dimension 3$ of the questionnaire "positive aspects of the application of the technique," have found significant differences between the 19-20 years and 23-24 years in the case of variable related to understanding the issues worked, where younger students had higher than average scores older, while the variable related to the organization of content differences were found between the group over 26 years with the group 2122 and 23-24 years, with older participants (+26 years) scored higher than the younger (21-22 and 23-24 years) scores.

Table 5: ANOVAs, differences by age in the variables of the student perception questionnaire about the process of learning the technique of Mind Mapping

\begin{tabular}{|c|c|c|c|c|c|c|c|c|}
\hline & Age & $\mathbf{N}$ & Mean & D.T. & gl & $\mathbf{W}$ & $\mathbf{P}$ & $\begin{array}{c}\text { Tukey/Game } \\
\text { s } \\
\text { Howel }\end{array}$ \\
\hline \multirow{6}{*}{$\begin{array}{l}\text { Variable: } \\
\text { DISTRESS }\end{array}$} & $19-2 O$ & 41 & 2.39 & .586 & & & & \\
\hline & $21-22$ & 23 & 2.57 & .896 & & & & \\
\hline & $23-24$ & 41 & 2.59 & .836 & 4 & 8.077 & $.000^{* *}$ & $23-24 \neq 19-20$ \\
\hline & $25-26$ & 8 & 2.00 & .535 & & & & $25-26 \neq 19-20$ \\
\hline & +26 & 14 & 2.29 & .914 & & & & \\
\hline & Total & 127 & 1.88 & .842 & & & & \\
\hline \multirow{6}{*}{$\begin{array}{l}\text { Variable: } \\
\text { SYNTHESIS }\end{array}$} & $19-20$ & 41 & 2.63 & .698 & & & & $19-20 \neq 25-26$ \\
\hline & $21-22$ & 23 & 2.52 & .593 & & & & \\
\hline & $23-24$ & 41 & 2.29 & .716 & 4 & 6.889 & $.000^{* *}$ & \\
\hline & $25-26$ & 8 & 1.88 & .354 & & & & \\
\hline & +26 & 14 & 2.86 & .770 & & & & \\
\hline & Total & 127 & 2.48 & .711 & & & & \\
\hline \multirow{6}{*}{$\begin{array}{l}\text { Variable: } \\
\text { COMPREHENSIO } \\
\text { N }\end{array}$} & $19-20$ & 41 & 3.10 & .625 & & & & $19-20 \neq 23-24$ \\
\hline & $20-21$ & 23 & 2.65 & .775 & & & & \\
\hline & $22-23$ & 40 & 2.63 & .740 & 4 & $3 \cdot 315$ & $.022^{*}$ & \\
\hline & $24-25$ & 8 & 3.13 & .641 & & & & \\
\hline & +26 & 14 & 3.14 & .864 & & & & \\
\hline & Total & 126 & 2.87 & .748 & & & & \\
\hline \multirow{6}{*}{$\begin{array}{l}\text { Variable: } \\
\text { ORGANIZATION }\end{array}$} & $19-2 O$ & 41 & 3.02 & .570 & & & & \\
\hline & $21-22$ & 23 & 2.83 & .778 & & & & $21-22 \neq+26$ \\
\hline & $23-24$ & 41 & 2.78 & .791 & 4 & 3.621 & $.014^{*}$ & $23-24 \neq+26$ \\
\hline & $25-26$ & 8 & 3.13 & .835 & & & & \\
\hline & +26 & 14 & 3.07 & .917 & & & & \\
\hline & Total & 127 & 2.92 & .741 & & & & \\
\hline
\end{tabular}

Finally, and as a compliment to the reliability of the instrument, a Pearson correlation was conducted on the questionnaire. Table 6 indicates the values of the Pearson coefficients that were reached between the dimensions of the questionnaire. The results indicated that there was a significant correlation between the dimension "feelings that arise during the learning of the technique" and the other two dimensions of emerging learning difficulties on learning the 
technique, and "positive aspects of the application of the technique". The correlation established between the size of the feelings that arise during learning and emerging dimension of learning difficulties was a moderate positive correlation (.532), ie, more feelings for most emerging learning difficulties, and vice versa. However, the correlation between the size of positive feelings and aspects of the application of the technique was a low negative correlation (-.260), meaning that more positive feelings for the less technical aspects of its implementation, and vice versa.

No significant correlation between the second and third dimension of the questionnaire was found. That is, the results did not establish relationships between items referring to the difficulties that emerge from learning the technique of mental mapping and items relating to the positive aspects that the application of the technique provides.

Table 6: Correlation coefficients between the dimensions of the questionnaire

\begin{tabular}{|c|c|c|c|}
\hline & $\begin{array}{l}\text { Feelings that arise } \\
\text { during learning } \\
\text { the technique }\end{array}$ & $\begin{array}{c}\text { Emerging } \\
\text { difficulties of } \\
\text { learning the } \\
\text { technique } \\
\end{array}$ & $\begin{array}{l}\text { Positive aspects of } \\
\text { the application of } \\
\text { the technique }\end{array}$ \\
\hline $\begin{array}{l}\text { Feelings that arise } \\
\text { during learning } \\
\text { the technique }\end{array}$ & & $\begin{array}{c}.532^{* *} \\
(107)\end{array}$ & $\begin{array}{c}-.260^{* *} \\
(126)\end{array}$ \\
\hline $\begin{array}{l}\text { Emerging } \\
\text { difficulties of } \\
\text { learning the } \\
\text { technique }\end{array}$ & & & $\begin{array}{l}-.056 \\
(105)\end{array}$ \\
\hline $\begin{array}{l}\text { Positive aspects of } \\
\text { the application of } \\
\text { the technique }\end{array}$ & & & \\
\hline $\begin{array}{l}{ }^{* *} \text { The correlation is si } \\
\text { * The correlation is sig } \\
\text { Number of participant }\end{array}$ & $\begin{array}{l}\text { ficative to a bilateral } \\
\text { icative to a bilateral o } \\
\text { N). }\end{array}$ & $\begin{array}{l}\text { level. } \\
\text { evel. }\end{array}$ & \\
\hline
\end{tabular}

\section{Discussion and conclusions}

This study collected the perceptions of students about learning the technique of Mind Mapping and their application to the university stage. Specifically, in this process three dimensions have been fully addressed and identified, as were the feelings that arise during learning, emerging difficulties of this process and the positive aspects of the application of the technique. In conclusion, we can say that students acknowledge to have found a number of difficulties in the learning process of Mind Mapping, as well as its realization. These stem from the confusion arising from the novelty of the technique as well as by strong methodological change, which has led to the emergence of certain negative states such as feelings of anxiety and confusion, resulting in an initial decrease in motivation and self-esteem. Throughout the process of learning the technique of Mind Mapping, the difficulties encountered by the awareness of the need for greater effort and commitment during this early stage have been overcome, which are crucial for effective learning (Muñoz, 2010).

Therefore, it seems that Mind Mapping is a technique that can be easily use in higher education, providing many advantages, both to students and staff, as it impacts on the development of skills related to compression, organization and storage of the contents worked. In this sense, the mind map can be used with any type of material, making it a tool applicable to subjects of any university.

It is essential in today's society to establish a learning orientation that addresses personal development entirely from the cognitive processes to a personal and social way at the same time, including the development of creativity and decision-making, not forgetting positive mental climate conducive to the process. Assuming that the student is the protagonist and builder of its own learning, it should help you to learn and become aware of what the process involves and how it 
is developed to regulate. Mind Mapping is a strategy / technique that attempts to respond to this idea of learning and allows the holistic development of the individual from these areas:

- Building knowledge and enhancing cognitive abilities in order to develop cognitive structures to enter the process of thinking, thereby exercise and development of mental abilities. Furthermore, with the use of the image, Mind Mapping encourage a variety of skills in the brain to operate with shapes, colors, lines, and dimensions that stimulate the imagination and therefore creative thinking is encouraged and memory.

- Working with self-consciousness involves mental maps of the processes experienced in the learning experience, ie metacognition which is a reflective self-awareness and a fundamental aspect of metacognition or self-regulatory basis of activity. In the field of learning, is the result of the involvement of the self in metacognitive, cognitive, affective and behavioral processes that are directly related to academic achievement (McCombs, 1993). If one of the fields or levels of metacognitive activity is self-awareness of their own learning, metacognition is a basic device to "learn to learn" and "learning to reflect." In this sense, we can say that metacognition is the key to learning to think, as it offers the students get the ability to control the learning situation and realizes the processes involved in learning.

In the words of Muñoz (2010), "learning involves the decision to engage in activities entailing personal, social and cognitive maturity, which requires commitment and liability arising from personal conviction. The initiative and autonomy in the functioning of the individual makes an indicator of the effectiveness and efficiency "(p. 394).

\section{References:}

1. Brysbaert, M. (2011). Basic Statistics for Psychologists. London: Palgrave Macmillan.

2. Buzán, T. (1996). El libro de los Mapas Mentales. Cómo utilizar al máximo la capacidad de tú mente. Barcelona: Urano.

3. Buzán, T. (2004). Tu mente en forma. Barcelona: Urano.

4. Carter, R. (2002). El nuevo mapa del cerebro. Barcelona: Integral RBA libros S.A.

5. Cohen, J. (1977). Statistical Power Analysis for the Behavioral Sciences. New York: Academic Press.

6. Dürsteller, J. C. (2000). Visualización de la información. Una visita guiada. Barcelona: Gestión 2000.com.

7. Engelhart, Y. (2002). "The language of graphics". Diagrammatic Representation and Inference. Pp. 104-108. Heidelberg: Springer Berlin.

8. Field, A. (2009). Discovering Statistics using SPSS. London: SAGE.

9. Gardner, H. (1994). Inteligencias múltiples. Barcelona: Paidós.

10. Goleman, D. (1994). Inteligencia emocional. Barcelona: Kairós.

11. Goleman, D (2006). Inteligencia social. La nueva ciencia de las relaciones humanas. (2006). Barcelona: Kairós.

12. Herrmann, M. (1989). The creative brain. Búfalo: Brain books.

13. McCarthy, M. J. (1991) Domine la era de la información. Barcelona: Robin-Book.

14. MacLean, P. (1990). The triune brain evolution. New York: Plenun Press.

15. McCombs. B. L. (1993). Intervenciones educativas para potenciar la metacognición y el aprendizaje autorregulado. En Beltrán, J. A., y otros: Intervención psicopedagógica. Madrid: Pirámide.

16. Mateo, J. (2006). La investigación ex post-facto. En R. Bisquerra (coord.). Metodología de la investigación educativa. (pp. 195-230). Madrid: La Muralla.

17. Muñoz, J.M. (2010). Los mapas mentales como técnica para integrar y potenciar el aprendizaje holístico en la formación inicial de maestros y maestras. Córdoba, Servicio de publicaciones de la Universidad de Córdoba.

18. Muñoz, J.M.; Serrano, R. y Marín, V. (2014). Innovación educativa sobre aprendizaje colaborativo y el uso de mapas mentales en la formación inicial docente. Educatio Siglo XXI, Vol. $32 \mathrm{n}^{0}$ 2, pp. 193-212

19. Ontoria, A., Gómez, J. P. y Molina, A (2007, $4^{\text {a }}$ edic). Potenciar la capacidad de aprender y pensar. Madrid, Narcea. 
20. Ontoria, A. Gómez, J. P., Molina, A y Luque, A, De (2006, $4^{\text {a }}$ edic.). Aprender con Mapas Mentales. Madrid, Narcea.

21. Pardo, A., y Ruiz, M. (2002). Guía para el Análisis de Datos. Madrid: McGrawHill.

22. Sperry, R. (1973). Lateral specialization of cerebral function in the surgically separated hemispheres. en F.J. McGuigan (Ed.). The Psychophi-sioly of the thinking. New York, Academic Press.

23. Tufte, E. (1994): Envisioning Information. Cheshire, Connecticut, Graphic Press.

24. Ware, C. (2004). Information Visualization: Perception for design. San Francisco (USA), Morgan Kaufmann Publishers Inc. 